Florida International University FIU Digital Commons

FIU Electronic Theses and Dissertations

University Graduate School

10-16-2015

\title{
Women Creators: Artistry and Sacrifice in the Novels of Virginia Woolf
}

Issel M. Guigou

Florida International University, iguig001@fiu.edu

DOI: 10.25148 /etd.FIDC000140

Follow this and additional works at: https://digitalcommons.fiu.edu/etd

Part of the Literature in English, British Isles Commons, and the Modern Literature Commons

\section{Recommended Citation}

Guigou, Issel M., "Women Creators: Artistry and Sacrifice in the Novels of Virginia Woolf" (2015). FIU Electronic Theses and Dissertations. 2250.

https://digitalcommons.fiu.edu/etd/2250

This work is brought to you for free and open access by the University Graduate School at FIU Digital Commons. It has been accepted for inclusion in FIU Electronic Theses and Dissertations by an authorized administrator of FIU Digital Commons. For more information, please contact dcc@fiu.edu. 


\title{
FLORIDA INTERNATIONAL UNIVERSITY
}

\author{
Miami, Florida
}

\section{WOMEN CREATORS: ARTISTRY AND SACRIFICE IN THE NOVELS OF VIRGINIA WOOLF}

\author{
A thesis submitted in partial fulfillment of the \\ requirements for the degree of \\ MASTER OF ARTS \\ in \\ ENGLISH \\ by
}

Issel M. Guigou

2015 
To: Dean Michael R. Heithaus

College of Arts and Sciences

This thesis, written by Issel M. Guigou, and entitled Women Creators: Artistry and Sacrifice in the Novels of Virginia Woolf, having been approved in respect to style and intellectual content, is referred to you for judgment.

We have read this thesis and recommend that it be approved.

Nathaniel Cadle

Maneck H. Daruwala

Date of Defense: October 16, 2015

The thesis of Issel M. Guigou is approved.

$\begin{array}{r}\hline \begin{array}{r}\text { Dean Michael R. Heithaus } \\ \text { College of Arts and Sciences }\end{array} \\ \hline \begin{array}{r}\text { Dean Lakshmi N. Reddi } \\ \text { University Graduate School }\end{array}\end{array}$

Florida International University, 2015 


\section{DEDICATION}

I dedicate this thesis to my parents, for their inexhaustible patience, and to my grandmother, for her indispensable help with my early English education. 


\section{ABSTRACT OF THE THESIS}

\section{WOMEN CREATORS: ARTISTRY AND SACRIFICE IN THE NOVELS OF VIRGINIA WOOLF \\ by}

Issel M. Guigou

Florida International University, 2015

Miami, Florida

Professor Michael Patrick Gillespie, Major Professor

This thesis examines different facets of feminine artistry in Virginia Woolf's novels with the purpose of defining her conception of women artists and the role sacrifice plays in it. The project follows characters in "Mrs. Dalloway," "To the Lighthouse," and "Between the Acts" as they attempt to create art despite society's restrictions; it studies the suffering these women experience under regimented institutions and arbitrary gender roles.

From Woolf's earlier texts to her last, she embraces the uncertainty of identity, even as she portrays the artist's sacrifice in the early-to-mid twentieth century, specifically as the creative female identity fights to adapt to male-dominated spaces. Through a close-reading approach coupled with biographical and historical research, this thesis concludes that although the narratives of Woolf's novels demand the woman artist sacrifice for the sake of pursuing creation, Woolf praises the attempt and considers it a crueler fate to live with unfulfilled potential. 


\section{TABLE OF CONTENTS}

CHAPTER

PAGE

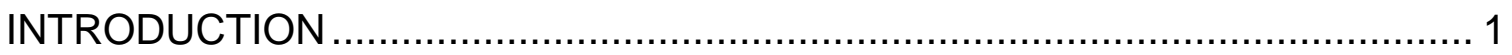

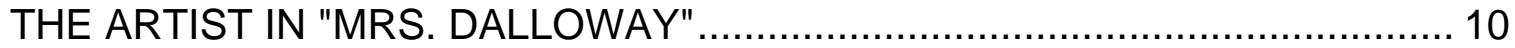

"TO THE LIGHTHOUSE":

THE THREATENING ILLUSION OF THE SPHERES ….............................. 32

THE ARTIST'S SACRIFICE IN "BETWEEN THE ACTS" ............................... 48

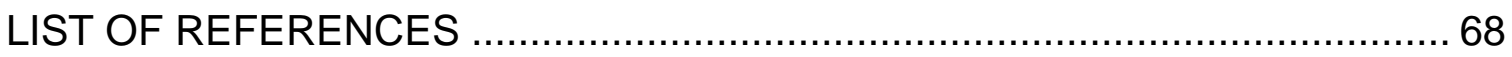




\section{INTRODUCTION}

Virginia Woolf explores different facets of feminine artistry in her novels Mrs. Dalloway (1925), To the Lighthouse (1927), and Between the Acts (1941). With the characters of Clarissa Dalloway, Lily Briscoe, and Isa Oliver, Woolf presents artists who work and aspire to create in different media, and she ascribes great worth to their endeavors while showing aversion toward the institutions which keep them subjugated and regimented in strict roles. Her novels ultimately demonstrate that women can still achieve creation and artistry under these circumstances.

Clarissa has reworked the perception of the society hostess to transform her persona into a performance piece, her parties into moving episodes for her guests. Lily paints, and through her painting, Woolf allows her to process her experiences and create something new out of them. In both cases, Woolf illustrates the negative impact of their detractors - presented as obstacles preventing personal growth, and armed with all of society's institutional might. Through Isa, a woman in possession of artistic inclinations yet wary of making a sacrifice to nurture them, Woolf communicates the calamity of a listless soul trapped in the drudgery of a role set before her by the momentum of tradition. In due course, Isa must make a choice, and although society in Woolf's works cruelly demands a sacrifice from the artist, the alternative of living with unfulfilled and unnamed aspirations is much worse than any sacrifice made in the name of creation. 
Woolf shares the modernist trait of mistrusting institutions. Karen Smythe writes, "The fictional form as developed by such modernist writers as Woolf provides a public forum for the staging of their 'general cultural malaise"' (64). This thesis concerns itself primarily with Woolf's dissatisfaction with and rejection of the traditional family and obligatory gender norms, particularly as it pertains to women artists. Woolf's work corresponds with Julia Kristeva's view of the feminist struggle; Toril Moi outlines this in the introduction to Sexual/Textual Politics: "Women reject the dichotomy between masculine and feminine as metaphysical... [a position which] has deconstructed the opposition between masculinity and femininity" (12). Woolf engages gendered notions in order to refute them. With particular concern for women artists, Mrs. Dalloway, To the Lighthouse, and Between the Acts make a case for freedom from the illogical yet mandatory binaries pushed onto the genders in the name of upholding order.

Indeed, forcing people into these roles only results in stagnation, and Woolf recognizes society's need for change at an individual level. As Hermione Lee writes in her biography of Woolf, "If you put Virginia Woolf's scattered writings on biography together, you can see her making up some rules. There must be these sharp moments, caught from the context, the subject's social world. But also there must be movement and change: generalisations, fixed attitudes, summings-up, are fatal. A good biography...is the record of the things that change rather than of the things that happen" (11). A life well lived contains multitudes and creation. A society that turns women into wives and mothers with no regard to their inclinations - with no mercy given in the face of their suffering 
and claustrophobia - is a society doomed to paralysis and decay as it kills possible progress every time a woman births another baby girl, robbing its people of her advancement.

The argument in this thesis consists of readings of these three novels Mrs. Dalloway, To the Lighthouse, and Between the Acts - following Woolf as she delves into the lives of creative women. One can analyze the themes communicated in her writing, which center on portrayals of female creation and the sacrifices this creation demands. By drawing a line from Woolf's earlier texts to her last, one can explore the manner in which she embraces the uncertainty of identity, even as she conveys the artist's sacrifice in the early-to-mid twentieth century, specifically as the creative female identity fights to adapt to maledominated spaces.

Throughout her works, a number of Woolf's varied female characters choose to live as artists, and in her explorations of their artistic creation, Woolf develops people who embody the losses women artists must accept in order to eke out an existence. In To the Lighthouse, Lily Briscoe, a painter, must be strong enough to defy the expectations of the time as she lives on the fringes of a society which dismisses her as an artist and devalues her as a woman by calling her a spinster. Even when presented with the seemingly comfortable existence of conventional women, she resists surrendering to the domestic order. Although she must contend with social isolation, she finds freedom and strength in the chaos of creative work. 
On the surface, Mrs. Dalloway's titular character differs from women who act on creative impulses, and one could stand to read Clarissa as an example of womanhood forced to submit to the masculine requirement that she yield and serve. And yes, we can consider Clarissa an excellent housewife, but her life is her creation, her parties and the details therein. She constantly represses inclinations which would undermine the persona she performs, denying every thought that threatens the cohesive version of her identity as the perfect party hostess, for her presence is her artwork. Crucially, we know that Clarissa takes genuine pleasure in her life, and delights in even the miniscule particulars of her society work.

Indeed, Woolf often intimates that a true consistent self cannot naturally exist within an individual, and as such, we can gather that a singular self can only be a fabrication, a work of deliberate creation (Caramagno 17). Thus, Clarissa Dalloway must channel her creative force, inventing a streamlined, cohesive personality at the expense of presenting a multidimensional identity. Like artists working in traditional media, who will strive to channel a conflicting personality into their work, Clarissa entirely surrenders herself to her vision; her life's work culminates in her performance. As she chooses to build upon her dominance over the social hierarchy, she does more than create art; instead, she becomes the artwork. Still, Clarissa sacrifices love and intimacy in order to live out her vision. She needs distance and solitude to gather her social and creative energies, and Woolf shows us that she has let go of close relations who would have threatened this effort. She forgoes marriage with Peter Walsh because he 
would not tolerate her thoughts diverging from his, and her girlhood dalliances with Sally Seton, had they become more serious, would have probably barred her from her chosen audience.

If we propose that one's identity can be created from an amalgam of memory and wants, then it follows that Woolf's Clarissa channels her creativity into mastering the illusion of a solid personality, taking control of the traditional feminine role, even at the expense of any suppressed desires. She succeeds in re-contextualizing for herself the position of the respectable party hostess. Her life involves more than serving men and society. She takes pleasure for herself, and so she secures a sense of purpose and vitality, which she passes to others as she shares her art.

Therefore, one can argue Woolf considers the self-creation of an identity to be a valid endeavor in the creation of art, provided that the artist gains fulfillment and understanding through the work. She then makes sure to expose the damaging effects prescriptive notions of any sort often have on the artist. For example, to contrast a woman like Lily Briscoe, Woolf places her in conflict with a traditional matriarch, the ever-nurturing and marriage-obsessive Mrs. Ramsay. A capable housewife, actively charitable, Mrs. Ramsay intends on turning every unattached lady she meets into a bride, always ready to provide comfort for her husband as a primary concern. Woolf condemns the traditional gender norms which make it difficult for a woman to earnestly pursue art, represented in the novel by gatekeeper Charles Tansley, which outright refuse her entry into 
education and history, trapping her within the constrictive expectations of womanhood, marriage and family; Lily feels the rejection dearly as she grapples with Mrs. Ramsay and Tansley - both products and defenders of these norms. Good modernist that she is, of course, Woolf often underlines the arbitrary nature of gender roles and the superficiality of ranking them. As she writes in A Room of One's Own when the narrator is denied access to an Oxbridge library, "That a famous library has been cursed by a woman is a matter of complete indifference to a famous library" (8). No objective truth exists to support society's treatment of itself.

More importantly, Woolf does not attack traditional feminine arts concerned with keeping a home and forging human relationships. Her arguments against the dictatorial also extend to Peter Walsh and Miss Kilman in Mrs. Dalloway, who insist talent is wasted in gaining skills for traditional feminine pursuits, and so concluding that Clarissa's work can have no value. They demand that she adopt their point of view and their methods, completely disregarding the transformative effect that her parties - well-crafted experiences that they are - have on her guests and on Clarissa herself. Unlike them, Woolf gives credibility to feminine work, so long as the artist finds gratification.

By social necessity in our rigid world, it seems that the life of the woman artist who works in a traditional medium demands sacrifices that Clarissa does not accept. After all, Clarissa's work requires that she be welcomed within reputable society; these people function as her audience. Yet if, unlike Clarissa, 
a woman cannot transform the narrow scope of traditional feminine roles into art, she will experience either the loss of artistic expression or the loss of belonging Woolf issues repercussions for both outcomes. Woolf's ongoing struggle, which she often documents in her autobiographical writings, echoes through the character of Isa Oliver in Between the Acts. Throughout the novel, we see Isa fluctuate between possibilities, writing poetry in secret, repressing feelings of frustration with her life as a housewife, and often losing her way in her own mind. In the novel, Woolf unveils Isa in a phase of potential transformation away from following the feminine order to perhaps deviating into poetic expression.

As Theresa L. Crater asserts in "Lily Briscoe's Vision: The Articulation of Silence," Lily may be the first of Woolf's characters who survives deviating from societal norms: "Lily Briscoe is not willing to be martyred...and finds an alternative to the identity they offer through her art. She explores the gap between her own daily experience and the ideology pressed upon her; she dives into the underwater world of consciousness, and is the first of Woolf's characters to survive the passage, to return and create from this gap, establishing new cultural alternatives" (125). Lily manages to push through life with her creative victories, and these victories save Lily even as she sacrifices her social standing. In Between the Acts, although Isa has been part of the audience for the duration of the novel, the narrative leaves us with an open ending, toying with the notion that Isa will allow herself to become a poet, to transition away from the domestic sphere and into a state of artistic creativity, permitting the reading that Woolf intends to save her as well. 
Therefore, we find in Woolf's novels women artists who must either sacrifice social comfort in exchange for the freedom to create art, or compromise freedom in order to work within the boundaries set by society while still crafting an identity, the performance of which allows them to succeed in that society. In both scenarios, the woman encounters loss, yet gains something else for herself. Clarissa Dalloway shapes the raw materials of her conflicting desires in the effort to epitomize the idea of domestic perfection, and her persona becomes her single portrait. She does not simply submit to the gender requirements of her time, but she actively embraces them and excels; however, this comes at the cost of intimacy, and she does suffer for it. Lily Briscoe endures social censure for the sake of remaining unmarried and working on her painting, but Woolf lets her grow in her craft regardless.

Isa Oliver needs to make a choice; she can either convert her traditional role into a mode of expression or quit and pursue poetry exclusively and against the prescriptions of polite society. Alternatively, she can do nothing and continue stumbling through unfulfilling unhappiness in a life characterized by dissociation, seething when she must attend to her house and husband yet shying away when she could share her poetry. Woolf illustrates the sacrifices creative women need to make as they attempt to live in this imperfect world, but in Between the Acts, she tells us that there is a worse option still, one which silences women and forces their submission. 
In her writing about these artists, Woolf outlines the differences between internal and external pressures, but confirms their origins in social institutions. Clarissa checks her own contrary needs according to her idea of perfection; society celebrates her, but it comes at the price of self-policing. Nevertheless, she succeeds in evolving and in conveying her vision to her audience. Conversely, Lily battles against a culture united in its need to undermine her artistic pursuits, attempting to convince her that she and her kind will never make successful artists, yet she gains insight, vision, through her painting. Isa Oliver cannot reach contentment within her homemaker facade. The chores of marriage and motherhood bring her no satisfaction; throughout the novel, her mind constantly snatches at poetry to entertain and comfort herself, using it as a buffer to separate her from the banality happening around her. Woolf indicates that Isa needs to create as Lily and Clarissa need to create, to make something vibrant out of her life. After all, the astonishing malleability of humanity extends far beyond the reaches of the arbitrary limits society sets for itself. 


\section{THE ARTIST IN "MRS. DALLOWAY"}

Virginia Woolf explores the artist-as-hostess in her novel Mrs. Dalloway, elevating its protagonist's skill as a party hostess to the heights of a deliberate and nuanced artistic performance. Throughout the novel, which covers a day in her life, Clarissa Dalloway prepares the details for her party as she meditates on her past and interacts with the people in her life. The novel (and Clarissa's efforts) culminates with that night's party, in which she basks in a moment of transcendence through her performance; Clarissa creates herself. As Thomas Caramagno writes in The Flight of the Mind: Virginia Woolf's Art and Manic Depressive IIIness, the self can become "both real and invented, like a work of art" (73). Clarissa creates a masterpiece with the tools of a hostess, and like an artist, she makes sacrifices for the sake of animating her vision.

To give weight to this performative creation, Woolf assigns Clarissa many of the artist's attributes. Clarissa's art does not require that she sacrifice her status as a wealthy woman. Instead, she works within the framework of her gender and class to create masterpieces out of the events she hosts. Still, she must make sacrifices in order to have the power to practice her art, in a way reminiscent of the struggles of other female artists - such as Lily Briscoe, a painter in Woolf's To the Lighthouse. Clarissa suffers many of the insecurities inherent in the trials of creating something new. And much like an artist, Clarissa finds comfort in musing over the details of her work when faced with the more unpleasant occurrences in her life; she can transcend the pettiness of the world in the pursuit of achieving her definition of artistic success. Clarissa thus 
maintains her way of life despite the frequent disapproval from the prescriptive would-be progressive members of her society, Miss Kilman and Peter Walsh, who belittle her hosting achievements in the name of some nebulous ideal of a woman reaching intellectual freedom through precise and correct means, in accordance with their particular views.

In the opening to her novel, Woolf opts to introduce Clarissa with the title of Mrs., alluding more to the society wife persona than to a husband, before establishing Clarissa's inner life with her given name and peeling back a layer so that we may know the artist behind the work: "Mrs. Dalloway said she would buy the flowers herself. For Lucy had her work cut out for her. The doors would be taken off their hinges; Rumpelmayer's men were coming. And then, thought Clarissa Dalloway, what a morning — fresh as if issued to children on a beach" (3). Woolf also reminds us that Clarissa belongs to the sort of social class which allows for maids, workmen, and the leisure of buying flowers. The trappings of such a bourgeois lady would not immediately register as a valid object in a traditional evaluation of artistry. Fortunately, in her imagining of this particular housewife, Woolf shows us that art can also occur within the historically feminine craft of hosting, and Clarissa's class privileges function as her tools. A party, when hosted with skill, can become an experience, and the skillful hostess performs her identity into art.

Doubtless, the society which raised Clarissa has limited her experiences, but she has managed to accept her circumstances and create within them, without yearning for the world which has snubbed her by virtue of her gender. For 
example, unlike an academic influenced by the patriarchal pastoral art movement (that which elevates and romanticizes a "simple" rural way of life), Clarissa submerges fully into the world she already knows:

Such fools we are, she thought, crossing Victoria Street. For Heaven only knows why one loves it so, how one sees it so, making it up, building it round one, tumbling it, creating it every moment afresh...In people's eyes, in the swing, tramp, and trudge; in the bellow and the uproar; the carriages, motor cars, omnibuses, vans, sandwich men shuffling and swinging; brass bands; barrel organs; in the triumph and the jingle and the strange high singing of some aeroplane overhead was what she loved; life; London; this moment of June. (4)

She appreciates urban London and does not acknowledge any inadequacy some might connect to her preferences.

Clarissa has confidence in her judgment of her own sensations; she lets them stand whole because they are truthful. She loves London and her senses delight in it. She therefore lets her pleasure expand and grow in complexity, independent of what some perceived authoritarian third-party might think of her for it. Jacob Littleton muses on this passage in "Mrs. Dalloway: Portrait of the Artist as a Middle-Aged Woman," asserting, "She neither condemns what seems like an altogether noisy and irritating urban scene (her London is not a Waste Land), nor approves it with the air of a connoisseur; her appreciation depends only on experience. In fact, her delight is free of self-interest or discrimination. She does not appreciate the scene for what it is, but simply because it is. Her 
world view is suffused with the sense of the solemnity and wonder of existence, but most of all by the wonder of living; she takes life very seriously" (37). As a woman practicing her art outside of the establishment, Clarissa has the freedom to rely on her observations, without the need to appeal to the elite. She compensates for the gaps in her education by paying unusual attention to her surroundings, cataloguing her experiences in the present to relive them in the future.

Indeed, Clarissa's education has failed her and she lacks a certain broad knowledge of the wider world to contextualize some of her endeavors. Yet without the need to adhere to a curriculum, she has the freedom to accumulate experiential wisdom to more than supplement the miniscule scope of formal instruction. She lacks scholarly conventions of form and style, so no artistic institution can accept Clarissa; therefore, no tradition pressures her to further constrict her ambitions within a specific mold. She lives in the chaos of London, and Woolf lets her enjoy it by deploying positive, exciting language; the "aeroplane" does not deafen - it sings to her. Here is the world in which Clarissa performs her art, and she accepts it wholeheartedly, making it her domain. She does not aspire to become an artist; she already is an artist to the point of being her own creation.

Consistent with her appreciation for the time and place in which she finds herself, Clarissa also acknowledges the influence of the traditions borne of past generations of women. "[And] she, too, loving it as she did with an absurd and faithful passion, being part of it, since her people were courtiers once in the time 
of the Georges, she, too, was going that very night to kindle and illuminate; to give her party" (5). She will not discard the traditional feminine pursuits in order to create, but she has instead become comfortable within them, able to transcend. As Littleton observes, "[It] should not be thought that Clarissa consciously felt trapped by this condition; in fact, she admires her class and culture...She loves the activities open to her without considering them secondary to or a substitute for pursuits more overtly intellectual. These activities constitute a separate female inheritance, and there was no Keats or Tolstoy in the female tradition" (52). She has adapted her desires to her circumstances and her knowledge, able to pursue her artistic intentions within her parameters.

But lest we forget it, Woolf does make explicit the inadequacy of Clarissa's formal education: "Not that she thought herself clever, or much out of the ordinary. How she had got through life on the few twigs of knowledge Fräulein Daniels gave them she could not think. She knew nothing; no language, no history; she scarcely read a book now, except memoirs in bed; and yet to her it was absolutely absorbing; all this; the cabs passing; and she would not say of Peter, she would not say of herself, I am this, I am that" (8). The educational institution of Clarissa's childhood provided very little instruction in the event that she might have wanted to pursue something less traditional and feminine. When considering her delight and interest in the material world, we may deduce that a young Clarissa might have thirsted for knowledge and understanding. Indeed, her dalliances with books and Sally Seton point to such a conclusion, as Clarissa 
remembers her days with Sally, sprinkled with reading and new ideas (33). But crucially, Clarissa still develops her perception despite these formal limitations.

In fact, her deficient education, when combined with her experiences within the feminine sphere, works as a catalyst in her quest to find the best way to interact with reality. "With her 'horror of psychological engulfment' (Henke 139), she rejects society's common props against the void: Walsh's passion, Kilman's religion, Bradshaw's Proportion, the simplistic patriotism of her husband and Lady Bruton. As a result, she must face disordered reality without accepted props and create her own meaning for it" (Littleton 37). She never tends toward these blinkered schools of thought, and any attempts made to convert her to them only succeed in repulsing her further. She would rather strive toward an individual approach, bespoke to the shape of her intuition.

Miss Kilman's unyielding slant, therefore, grates on Clarissa's sensibilities. "Love and religion! thought Clarissa, going back into the drawing-room, tingling all over. How detestable, how detestable they are! For now that the body of Miss Kilman was not before her, it overwhelmed her — the idea. The cruelest things in the world, she thought...love and religion. Had she ever tried to convert any one herself? Did she not wish everybody merely to be themselves?" (126). Clarissa feels contempt toward religion and its authoritarian notions, and consequently she resists the idea of similarly drafting other people into her particular way of life.

Much unlike Mrs. Ramsay's matchmaking with a view toward marriage in To the Lighthouse, Clarissa refrains from overriding her daughter's natural 
inclinations. Also crucially unlike Mrs. Ramsay, Clarissa finds artistic contentment in her life and her created self and thus upholds an individualistic approach to living. Although she dislikes Miss Kilman, she nevertheless allows her presence in Elizabeth's life, and while Clarissa might prefer it if her daughter were to grow into a charming socialite, the prevailing concern lies with the rigidity of Elizabeth's chosen mentor. What rankles from Kilman are the arguments against the value of a hostess; Kilman acts as prescriptively as the upholders of the patriarchy, denigrating traditional female pursuits as the height of frivolity.

Notably, Clarissa begins her denunciation with complaints of love, which, in regard to her youthful relationship with Peter Walsh at least, she has found counterproductive to her inclinations. As we will see later, Walsh and Kilman share a similar view regarding Clarissa's feminine arts. Yet, Woolf does leave some room to asses Clarissa's dislike of Miss Kilman as originating from upperclass guilt: perhaps Clarissa hates the reminder of what happens when women cannot live lavishly, when they refuse to submit dutifully to society's expectations of female intellect. "[Miss Kilman] was never in the room five minutes without making you feel her superiority, your inferiority; how poor she was; how rich you were...it was not her one hated but the idea of her" (12). Still, considering Clarissa an artist and an individual provokes a layered reading, accepting that Kilman's ideals are limiting, unable to recognize a woman's freedom to do as she chooses and value it how she will.

Perhaps to legitimize further Clarissa's choices as an artist, Woolf presents her as liable to succumb to typical artists' predicaments, such as 
suspicions of growing inadequacy: "How year by year her share was sliced; how little the margin that remained was capable any longer of stretching, of absorbing, as in the youthful years, the colours, salts, tones of existence, so that she filled the room she entered" (30). In this passage, where the aging process appears to threaten Clarissa's creation, she suffers through the anxieties inherent in creating art, the constant need to evaluate one's progress, to gauge skills and success.

In a way, here Clarissa is akin to a prima ballerina as she perceives the dwindling of time and the aging of her body, dreading the inability to perform with the precision and grace she has had in the past, wondering if she can breathe life into her vision. "She could see what she lacked. It was not beauty; it was not mind. It was something central which permeated; something warm which broke up surfaces and rippled the cold contact of man and woman, or of women together" (31). Woolf forces Clarissa to dwell upon her failures, attributing them to an inbuilt lack within her which she cannot overcome.

Here we may see Woolf's creation ape her maker; in a passage from her diaries, Woolf dwells upon her own worries in writing Mrs. Dalloway: "After a dose of criticism I feel that I'm writing sideways, using only an angle of my mind...I should like to write away and away at it, very quick and fierce. Needless to say, I can't. In three weeks from today, I shall be dried up" (Writer's Diary 56). Painter Lily Briscoe's struggles echo these feelings in To The Lighthouse, reflect them in much the same way as she fails to satisfy her own standards and falls into despair as she contemplates her work and its worth: "She could have wept. It 
was bad, it was bad, it was infinitely bad!" (Lighthouse 54). All three of these artists are familiar with the concept of creating within uncertainty, fleeing the world of absolutes for the chance of grasping something more profound, and often fighting to continue against their perceived inadequacies when the reality of the work attempts to betray their vision.

In Mrs. Dalloway, Woolf dutifully assigns massive significance to the moments in which Clarissa labors over the details of her artwork. "Quiet descended on her, calm, content, as her needle, drawing the silk smoothly to its gentle pause, collected the green folds together and attached them, very lightly, to the belt. So on a summer's day waves collect, overbalance, and fall; collect and fall; and the whole world seems to be saying 'that is all' more and more ponderously, until even the heart in the body which lies in the sun on the beach says too, That is all" (39). Woolf connects Clarissa, sewing in solitude, to waves and to ponderous, unified nature - not merely pretty flowers and gentle birdsong. Clarissa transcends through her art, in her solitude, as she mends the dress that she will wear for the party.

Although Woolf tells us Clarissa commandeered the quiet room as a result of a prolonged illness, we see her claim this space as a chamber of rebirth and contemplation, simulating the manner in which she conquered her fate as a housewife. In this room, the artist pulls out her materials for inspection, like a painter looking over the quality of her brushes, mulling over the new piece that she will begin. This solitude lives in parallel with Woolf's ideas as developed in $A$ Room of One's Own, where she asserts that artistic creation requires one's own 
physical space, apart from the demands of the world. As Clarissa fixes the dress and thinks of her party, she enters a meditative moment away from her created persona. And perhaps an artist can only begin to create when she exists momentarily outside of the context of her works. Clarissa does not live in unwanted isolation; she has a haven.

She has won this sanctuary through her marriage to Richard Dalloway, a painful choice made in spite of her girlhood feelings for Walsh. Like Kilman, Walsh has always refused to concede Clarissa's worth, and this lack of regard causes their separation and makes possible the subsequent match with Mr. Dalloway - a man better willing to give her space to create for her chosen medium. In contrast, as an upholder of male dominion, Walsh often disparages Clarissa as he struggles with the validity in her forms of expression. "How he scolded her! How they argued! She would marry a Prime Minister and stand at the top of a staircase; the perfect hostess he called her (she had cried over it in her bedroom), she had the makings of the perfect hostess, he said" (7).

As a young woman, Clarissa has cried over being called the term she would later use to define her personality. Peter Walsh insults her excellence in feminine pursuits, claiming that he wants her to think for herself while dismissing her happiness. Indeed, Walsh wants a different kind of submission, whereupon Clarissa becomes a flatteringly distorted mirror for his philosophies. Walsh wears a cloak of nonconformity, yet he wants Clarissa to match his every misstep in a complementary manner. 
Alex Zwerdling points out in "Mrs. Dalloway and the Social System" that characters like Walsh represent the last days of an empire which has become ineffectual (70). Specifically, Zwerdling targets Walsh's failures abroad and his need to see himself as an individual and intellectual: "This compromised rebellion or permanently inhibited aggression is epitomized in the pocket knife Peter carries and is forever opening and closing, a weapon that becomes a toy in his hands" (77). Walsh's failures must force him to confront uncomfortable realities, but he struggles to meet them, choosing to belittle Clarissa instead of dealing with his ineptitude.

We may read further into the description of events from Walsh's meeting with Clarissa by remembering that she narrates the scene. She recollects the repetition of his proclamation, "perfect hostess," her heart's desire bent into inadequate shape. Walsh considers her aspirations with contempt, something which wounds Clarissa enough to remember it - periodically, one assumes. Yet, she attempts to brush aside the emotional significance; she cries in the parenthetical. The perfect hostess, the vision, does not cry. And the perfect hostess does not love Peter Walsh if he refuses to give her space to think and act.

Before her novel reaches the tenth page, Woolf has already outlined Clarissa's deliberate sacrificial act in the name of art. She has little power to escape her education and class, but she holds control in the matter of marriage. She could have followed love to join Walsh, but her art would have suffered; in order to become the perfect Angel in the House, Clarissa needs the space to be 
artistic, the privacy. "For in marriage a little license, a little independence there must be between people living together day in day out in the same house; which Richard gave her, and she him...But with Peter everything had to be shared; everything gone into. And it was intolerable" (8). She cannot endure the constant harassment of Walsh's narrow admonitions. Therefore, she sacrifices young love for the sake of a more convenient, more peaceful match with Mr. Dalloway, a man who can accept the normality of having a good hostess for a wife.

Still, Woolf inserts a moment of envy in the following passage: "though she had borne about with her for years like an arrow sticking in her heart the grief, the anguish; and then the horror of the moment when some one told her at a concert that he had married a woman met on the boat going to India!" (8). In confiding this detail regarding Clarissa's continuing feelings, Woolf underlines the nature of this sacrifice as ongoing. A female artist who wishes to work in a traditional medium - a writer, a painter - may encounter much in the way of social slight and discrimination. A woman who follows Clarissa's commitment to domestic arts and performance, who relies heavily on social status to fulfill her visions, cannot work in that exile. Thus, Clarissa practically accepts the need to sacrifice something else for art.

She accepts the sorrows because Clarissa, like many artists, wants immortality through her art:

Did it matter that she must inevitably cease completely; all this must go on without her...but that somehow in the streets of London, on the ebb and flow of things, here, there, she survived, Peter survived, lived in each 
other, she being part, she was positive, of the trees at home; of the house there, ugly, rambling all to bits and pieces as it was; part of people she had never met; being laid out like a mist between the people she knew best, who lifted her on their branches as she had seen the trees lift the mist, but it spread ever so far, her life, herself. (9)

Even as she works within people's personal moments and experiences, she hopes to influence them in such a way as to become more than the experience, to become a memorable sensation that withstands her death. Although Clarissa finds no consolation in the idea of a permanent soul, the artist needs to transcend her time and become more than her life, and she reaches emotional heights through material means.

Indeed, Clarissa admires a woman who puts away disparate wants for the sake of putting on a good performance: "Tears and sorrows; courage and endurance; a perfectly upright and stoical bearing. Think, for example, of the woman she admired most, Lady Bexborough, opening the bazaar" (10). In this instance, Lady Bexborough removes herself from the grief of her son's death for the sake of her event. While the broken part of her requires clemency, the bazaar and its duties call louder.

With this in mind, after Clarissa dismisses the life she might have led alongside Peter Walsh, Woolf shows us what her protagonist does value. "How much she wanted it - that people should look pleased as she came in...she thought, waiting to cross, half the time she did things not simply, not for themselves; but to make people think this or that" (10). Clarissa gives us her 
artist's manifesto. She does not do things for their immediate purpose, but for what these actions signify to her audience. Clarissa works in allegory.

Woolf then shows us Clarissa in her element, working on making this vision happen: "And as she began to go with Miss Pym from jar to jar, choosing, nonsense, nonsense, she said to herself, more and more gently, as if this beauty, this scent, this colour, and Miss Pym liking her, trusting her, were a wave which she let flow over her and surmount that hatred, that monster, surmount it all" (13). This section presents another instance of Clarissa's art transforming her, Mrs. Dalloway choosing her flowers, accompanied by a warm acquaintance of her own creation, wandering among beauty she will mold into the scenery of her party. Clarissa's agitation passes as she yields her concentration to creativity.

Before this, she finds distraction in remembrances of her young love. "But Peter - however beautiful the day might be, and the trees and the grass, and the little girl in pink - Peter never saw a thing of all that. He would put on his spectacles, if she told him to; he would look" (7). With this passage, Woolf presents us with the first pieces of evidence of Peter Walsh's general shortsightedness, which he later concentrates into a rather criminal misjudgment of Clarissa's worth and talent. Yet, as we glimpse throughout sections of the novel in which he is a concern, Walsh never becomes immune to Clarissa's artistry, even as he vocally diminishes its powers. Here, Clarissa admits that Peter can briefly expand his sight at her encouragement - because the artist forces her audience to look and feel differently, to notice. 
Peter insists on undermining the profundity of Clarissa's occupation as he also undermines her experiences: "Here she is mending her dress; mending her dress as usual, he thought; here she's been sitting all the time I've been in India; mending her dress; playing about; going to parties; running to the House and back and all that, he thought, growing more and more irritated, more and more agitated" (41). He believes he is superior to her preoccupation with appearance, despite hypocritically dressing rather well himself; he denies Clarissa's right to attain dignity however she can while fiercely asserting his own (41).

As he thinks of her unchanged, he snaps his knife. This very habit is, of course, a continuation of the past. Woolf notes that Clarissa does not see him as changed at all. Clarissa recognizes his stasis, even as she knows he is judging her on what he perceives to be her own. Although Clarissa's created appearance at the party affects him viscerally (as perhaps it always has), he cannot bear to acknowledge her power intellectually. He cannot see the waves even as they bear him up:

What is this terror? what is this ecstasy? he thought to himself. What is it that fills me with extraordinary excitement?

It is Clarissa, he said.

For there she was. (194)

The way Clarissa chooses to present herself at the party evokes the response owed to a striking piece of artwork. After all, as Lucian Krukowski tells us in "Appreciation, Obligation, and an Artwork's End," "We need not appreciate what 
we approve of; although we usually approve of the things we appreciate" (33). Clearly, Clarissa's art still overcomes Walsh's disapproval of her choices.

Walsh often denies Clarissa's individuality and skill by ascribing her attributes to the whole of her gender, categorizing them as the Woman's Gift: "[Clarissa was] purely feminine; with that extraordinary gift, that woman's gift, of making a world of her own wherever she happened to be. She came into a room; she stood, as he had often seen her, in a doorway with lots of people round her. But it was Clarissa one remembered. Not that she was striking; not beautiful at all; there was nothing picturesque about her; she never said anything specially clever; there she was, however; there she was" (75). Seemingly, to him, Clarissa's talents are universal to all women. Indeed, by disregarding motive and intent, one might confuse her daughter Elizabeth's passive entrance into womanhood with Clarissa's purposeful approach to her society life. To Walsh, a person dismissive of the world and artistry of women, Clarissa's specific and detailed performative choices become intellectually indistinguishable from any other society party hostess. Because he refuses to imagine the lives of women complexly, he fails to appreciate Clarissa's art outside of the intuitive effect it has over him. Ultimately, as we see during the party, her artistry maintains a subtle strength which overpowers his denial of it. Even though he refuses to engage with her pursuits, the trifles and pettiness of womancraft, he cannot help but be overcome when Clarissa reveals herself as a masterpiece, now transformed.

In this same party, Woolf leads us briefly to consider Elizabeth's role in the narrative as a woman who also receives significant attention from the guests: 
And already, even as she stood there, in her very well cut clothes, it was beginning. . . People were beginning to compare her to poplar trees, early dawn, hyacinths, fawns, running water, and garden lilies; and it made her life a burden to her, for she so much preferred being left alone to do what she liked in the country, but they would compare her to lilies, and she had to go to parties, and London was so dreary compared with being alone in the country with her father and the dogs. (134)

Elizabeth does not want to engage with her mother's world. Unfortunately for her, as evidenced by the guests' reactions at the party, she continues to affect people similarly despite doing little to cultivate her image. Still, we must be sure to distinguish her passive approach to her persona from her mother's dynamic invention of the self. The party guests compare her to pretty flowers, safe little animals, the nonthreatening children of nature. One might consider her an object of beauty, a trinket in her mother's collection.

If we knew this was Elizabeth's design, we might fairly attribute the artist's agency to her case, but by constantly reminding us of Elizabeth's distaste for matters of society, Woolf informs us that this effect lives outside of Elizabeth's intentions. As a result, we have room for interpreting her clothes as "well-cut" as a consequence of her social status, and not as an outward expression of her identity. Her dress is neither her craft nor art. Clarissa labors over her dress as meditation and anticipation, a moment for planning the details of the night and shouldering them through her apparel. The night hangs on her frame as it drapes 
the rooms she decorates. Unlike her pretty daughter, Clarissa deliberately stuns and enchants.

In this passage, Woolf tells us Elizabeth enjoys the approval of her father, but suffers the neglect of her dogs. "And Richard and Elizabeth were rather glad it was over, but Richard was proud of his daughter. And he had not meant to tell her, but he could not help telling her. He had looked at her, he said, and he had wondered, Who is that lovely girl? and it was his daughter! That did make her happy. But her poor dog was howling" (194). Woolf forces the compromise, one for the other, and Elizabeth lives wedged between her wants. As a member of society, Elizabeth receives encouragement for her excellent beauty, and this attention brings her complicated, shaded pleasure. Her father's approval lends her a sense of achievement, understandable in view of the closeness of their friendship. While in London, she longs for the company of her father and her dogs, and the joys of somewhat masculine rural pastimes. But, in order to maintain her father's happiness and the balance of their relationship, Elizabeth needs to succumb to his standards, which reflect the gendered values of the broader world. In his way, Mr. Dalloway exists as the reminder of the male sphere in Elizabeth's world. Her dogs howl against her father's satisfaction, and maybe Woolf means to warn us of the death of Elizabeth's self. Even though she yearns to stay in his world, her father, in his own seemingly benign way, wants her out and fully defined in a woman's position. If one believes that Elizabeth's longing for nature corresponds with the desire of artistic isolation, one may conclude institutions will force Elizabeth into bonded toil within a disagreeable 
medium, and she may never achieve artistic contentment. Clarissa, on the other hand, thinks little on the approval of others outside of her ability to affect them with her art and self, demonstrating artistic independence even when she must work with an audience to achieve her goals.

Sadly, Septimus Smith does not have the luxury of operating freely within the parameters society has inflicted upon him. The former poet finds that his country would rather he go to war as an able-bodied man of the lower-classes. He returns with an Italian wife and a desperate case of Post-Traumatic Stress Disorder.

Woolf makes explicit Septimus' role as a counterpart to Clarissa, helping illustrate Caramagno's point: "In order to 'authorize' herself, Woolf continually probed this connection between normal and abnormal mentality, letting each one inform the other, questioning not only emotion but the self-sane or insane" (73). She juxtaposes Clarissa's reality-based creativity with Septimus' unhinged hallucinations, borne of a once-creative mind in distress.

During her party, after his suicide, Clarissa becomes aware of Septimus and thinks on him directly:

Or there were the poets and thinkers. Suppose he had had that passion, and had gone to Sir William Bradshaw, a great doctor yet to her obscurely evil, without sex or lust, extremely polite to women, but capable of some indescribable outrage — forcing your soul, that was it - if this young man had gone to him, and Sir William had impressed him, like that, with his 
power, might he not then have said (indeed she felt it now), Life is made intolerable; they make life intolerable, men like that? (184)

When furnished with only little detail - the means of his treatment and his death Clarissa shows a deep understanding, damning the institutions that damned him. She knows what has led to his death, and we trust in her knowledge because we see that she has also suffered unfairness in the care of the institutions which have limited her.

Septimus' last thoughts revolve around getting away from the psychiatric treatment Holmes and Bradshaw would force upon him. The men encroach upon a moment of unity between Septimus and Rezia - unity and clarity being of utmost importance for Septimus. "Holmes was coming...It was their idea of tragedy, not his or Rezia's (for she was with him). Holmes and Bradshaw like that sort of thing. (He sat on the sill.) But he would wait till the very last moment. He did not want to die. Life was good. The sun hot. Only human beings - what did THEY want?" (149). Unlike Clarissa who often chooses solitude to focus on her art, Septimus lives somewhat in reclusion as he attempts to recover from the war, and the constant intrusions from single-minded society strengthen his aching for death. Institutions interfere when he least wants them, and they give him loneliness when he most requires loving company. He welcomes and cherishes his rediscovered intimacy with Rezia, who strives to form a strong bond with him, but the nagging recriminations of his doctors are a different matter entirely. 
Throughout the novel, Woolf has him struggle in isolation, and it is only with Bradshaw's denial of Rezia's final acceptance that Septimus musters the will to part ways with the world. "But Rezia laid her hands on [his poems]. Some were very beautiful, she thought. She would tie them up (for she had no envelope) with a piece of silk. Even if they took him, she said, she would go with him. They could not separate them against their wills, she said" (148). The institution which standardizes mental health insists that he needs isolation because he thinks differently; therefore, Rezia's acceptance of him here is, at best, wrongheaded and, at worst, an early sign of a similar affliction within her. "But he remembered Bradshaw said, 'The people we are most fond of are not good for us when we are ill.' Bradshaw said, he must be taught to rest. Bradshaw said they must be separated" (147). Despite Septimus' agonizing loneliness, Bradshaw insists on isolating him further by depriving him of the freedoms of the world and the friendly company of his wife.

Regarding the concept of solitude, we can contrast Septimus' agony in Ioneliness with Clarissa's delight with her attic room. The key difference is, of course, that Clarissa has art. She bears empathy for Septimus' curbed sensibilities. "Then (she had felt it only this morning) there was the terror; the overwhelming incapacity, one's parents giving it into one's hands, this life, to be lived to the end, to be walked with serenely; there was in the depths of her heart an awful fear" (185). Woolf here explores the darkness that lies underneath Clarissa's persona, showing that she has faced and understood the burden of living life in our world, but Woolf then provides further evidence of Clarissa's art 
as the savior. Duty to her party, her vision, her work, pulls Clarissa back from Septimus' fate. "She had once thrown a shilling into the Serpentine, never anything more. But he had flung it away. They went on living (she would have to go back; the rooms were still crowded; people kept on coming). They (all day she had been thinking of Bourton, of Peter, of Sally), they would grow old" (184). The particulars of her endeavor tug at her mind, reminding her that she has much to achieve before resting.

"A thing there was that mattered; a thing, wreathed about with chatter, defaced, obscured in her own life, let drop every day in corruption, lies, chatter. This he had preserved. Death was defiance. Death was an attempt to communicate" (Dalloway 184). She contemplates the comfort of death perhaps because she is too familiar with the lies involved in living. A lively soul like hers, deprived of art, must exist in lies and chatter, to obfuscate the changing nature of her complex being. She synthesizes her desires neatly, which must of course cause a dissonance as she denies the light to some inclinations; however, the reward is art that may be admired by everyone yet is created principally for Clarissa's own delight. She ultimately embraces creativity and its ability to save her, but she cannot forget the sacrifices involved in relinquishing other aspects of her intimate self. "She had a perpetual sense, as she watched the taxi cabs, of being out, out, far out to sea and alone; she always had the feeling that it was very, very dangerous to live even one day" (8). 
"TO THE LIGHTHOUSE": THE THREATENING ILLUSION OF THE SPHERES

Virginia Woolf's To the Lighthouse juxtaposes women's right to artistry against the notion of gendered spheres. Presaging arguments made later in $A$ Room of One's Own, Woolf shows us Lily Briscoe's struggle to create in an environment which needs to cajole her into accepting a more traditional role, pushing her to sacrifice her spinsterhood for married respectability. The forces of history and gender, here represented by Mrs. Ramsay and Charles Tansley, need her to conform, so that she may not disturb the order of the times - an order in which, for better or worse, they have become entrenched. Crucially, after much internal hardship, Woolf grants Lily the independence of her will, allowing her, the female artist, the novel's moment of discovery. Through focusing on art and unshackling herself from the dominance of male and female tradition, Lily can unite different facets of the human experience for the sake of art. Indeed, only when Lily conquers the influence of the spheres can she transcend through her vision and face the reality of her creation.

Lily must overcome the prescriptive notions set by the Victorian institutions concerned with gender, marriage, and family. The nineteenth century cemented the concept of the gender spheres, reliant upon the Angel of the House ideal: "It shows that the wife [is] the presiding hearth angel of Victorian social myth...The prevailing ideology regarded the house as a haven, a private domain opposed to the public sphere of commerce" (Langland 291). Although Elizabeth Langland asserts in "Nobody's Angels: Domestic Ideology and Middle-Class Women in the Victorian Novel" that the feminine sphere was not entirely without power - home 
politics can become politics - the dominance of the spheres cannot be denied. They worked in tandem to promote themselves (291). Late Victorian men became artists or scholars or bankers, as they chose, and their women would tend exclusively to the children and the home, lest they don the risky appearance of eccentricity. The ideology - not entirely foreign today - was pervasive in Victorian middle-class households which could afford to ignore the woman's potential income. It stands to reason that this gendered structure was protected by those within it, men and women alike, as they perceived this as the foundation for families, themselves the foundation of a working world.

Indeed, only a few years before the events of the novel, late Victorian education for girls involved a limited curriculum, with no thought given to the possibility of women becoming artists - at the very least, not artists in the public sense of the word (Fawcett 511). And although Woolf sets To the Lighthouse's "The Window" section in the twentieth century, women writing or painting publicly strikes a dissonant chord with Mrs. Ramsay and Charles Tansley, the representatives of the female and male dominions with regard to their effect on and interest in Lily's pursuits. These characters represent a microcosm of the wider world, as Tansley offhandedly dismisses Lily's work, and Mrs. Ramsay preaches on the interminable benefits of marriage. Both strive to preserve the status quo, continuing the legacy that they have inherited, regardless of any pain it may have caused them. As Lily Briscoe attempts to carve out moments in which to consider painting and to work on it freely, they stand beside her, 
invading her head, by turns distracting and discouraging, demanding attention and submission.

Woolf sets Lily as a clear anomaly in a narrative populated by scholarly and somewhat acceptably eccentric men and good-sporting young women - such as Minta - ready with an easy conversation and a marriage proposal. Mrs. Ramsay acts as the kindly matriarch to all, smoothing rough edges with ease, being quietly attractive and seemingly attentive. Working to be the perfect angel, she longs to draw everyone into her hearth, even people whom she finds occasionally disagreeable. She is charitable with what time she has left after tending to her family, taking to the street to spread her kindness to the poor and the unwed alike, offering bread to one and the promise of marital bliss to the other. Otherwise, Mrs. Ramsay is a woman devoted to her cause, the propagation of the feminine sphere. She wants to see it flourish and expand. She floats around the house, hoping to design tidy marriage matches among her guests.

One such example is the creation of "the Rayleys" - a new perfect union, specially crafted by her maternal fondness and constant needling:

All that would be revived again in the lives of Paul and Minta 'the Rayleys' - she tried the new name over; and she felt, with her hand on the nursery door, that community of feeling with other people which emotion gives as if the walls of partition had become so thin that practically (the feeling was one of relief and happiness) it was all one stream, and chairs, 
tables, maps, were hers, were theirs, it did not matter whose, and Paul and Minta would carry it on when she was dead. (129)

Woolf lays out Mrs. Ramsay's motivations clearly and directly. We can extrapolate a number of matters of interest in this passage, cloaked so heavily with allusions to the home. Here is Mrs. Ramsay's kingdom, and no one will defeat her, the agent of marriage and domestic bliss. In a way, the match between two people has been borne out of three, with Mrs. Ramsay as its supreme creator. Minta existed before, and so did Paul, two singular entities, perhaps occasionally bumping into each other. If the possibility of lifelong marriage exists before Mrs. Ramsay's interference, readers might be forgiven if they do not recognize it. Like the characters, we can only believe Mrs. Ramsay's assessment of their natural compatibility. Their future failed marriage per "The Lighthouse" section of the novel is yet too distant to consider, although it taints the memory of Mrs. Ramsay's skills, exposing fissures across the facade of conservative bliss. Yet in the eyes of the living, formidable Mrs. Ramsay, the legacy of the hearth stands, never diminished.

Indeed, her possessive feelings on the matter of marriage extend to her children. Mrs. Ramsay stands ready at the nursery door, glowing with prior successes, to introduce the spheres to her younglings. As she thinks regarding Prue when Minta comes engaged to the dinner table, "You will be as happy as she is one of these days. You will be much happier, she added, because you are my daughter, she meant; her own daughters must be happier than other people's daughters" (125). Woolf leaves readers wondering how Mrs. Ramsay may have 
intervened in her daughter's marriage, briefly mentioned in the "Time Passes" section, but we may argue, as Woolf covers Prue's married life and death in a couple of asides, that Prue has seemingly attempted to obey her mother's rules, accepting the legacy. Since we do not know the details of Prue's marriage, whether it is a happy, loving union of equals or a less loving retelling of Mrs. Ramsay's marriage, we may conclude that Woolf's narrative punishes attempts to adhere so forcefully to tradition.

Turning our attention back to Lily Briscoe's relationship with these same traditions, we can examine how Mrs. Ramsay - the living illustration of the feminine domain's almost irresistible influence upon a mind - works to try to win Lily over to her side, as well as Lily's defense against her. Mrs. Ramsay tends to dismiss Lily's painting as a simple hobby, choosing instead to consider her in terms of marriageability, and pitying her when she finds Lily lacking in some of the usual graces: "With her little Chinese eyes and her puckered-up face, she would never marry; one could not take her painting very seriously; she was an independent little creature" (19). Lily's assertions that her painting will be enough to sustain her spiritually, that she does not truly need to become a wife and raise children to find happiness, are ignored out-of-hand and Mrs. Ramsay continues insisting, deigning to understand only the traditional paradigm. Mrs. Ramsay refuses to see her life as a waste, and feels somewhat threatened by the thought that she has held different aspirations and has ever wanted to succeed outside of the home and charitable pursuits. 
Yet during dinner, Mrs. Ramsay lets us glimpse some of her dissatisfaction: "But what have I done with my life? thought Mrs. Ramsay, taking her place at the head of the table...Again she felt, as a fact without hostility, the sterility of men, for if she did not do it nobody would do it, and so, giving herself the little shake that one gives a watch that has stopped, the old familiar pulse began beating" (95). She briefly dissociates from her duties, needing then to forcibly return to her present actions and engage with her dinner guests. Woolf compares this housewife to a clock, leashed to the relentless goose step of time, forced to keep going until flaws in the mechanism erode it to uselessness. Even Lily notes that Mrs. Ramsay looks weary.

So, Mrs. Ramsay works to overcome this lapse and settles into the groove she has made for herself, superficially patching over her frustrations with her children and her husband's attitude. Though as Theresa L. Crater notes in "Lily Briscoe's Vision: The Articulation of Silence," Mrs. Ramsay's death, mentioned briefly in "Time Passes," ultimately portrays "what it costs women to become Woman and to give up their vital energy to serve men in this way" (126). Unlike Clarissa, the housewife who turns parties into masterpieces for her own pleasure in Woolf's Mrs. Dalloway, Mrs. Ramsay has cultivated a marriage that demands too much of her emotionally. Indeed, Clarissa admits that the charm of the Dalloway union lies in the independence both parties enjoy regarding their emotional distance, allowing her time and space to pursue her wants at length (8). Mrs. Ramsay, on the other hand, often represses her own desires in order to 
meet the demands of her family. She spends all of herself and wastes away, always prematurely cutting off her own pleasures.

Still, Mrs. Ramsay persists in ladling soup and smoothing over the conversation because, as far as Mrs. Ramsay admits, nothing worth pursuing exists outside of the home. When her husband requires soothing and primping, demanding affection at inconvenient times and in inconvenient ways, Mrs. Ramsay accepts it as a quirk of their relationship, perhaps somewhat flawed, but not fatally so. The woman nurtures, and she is happy when she sees her family flourish and multiply; nothing missing, nothing wrong in the traditional feminine condition. In fact, "she pitied men always as if they lacked something - women never, as if they had something" (97).

Mrs. Ramsay's society dictates women must learn to comfort because men need the comfort; they feel dependent upon the women for this above all else. "It was sympathy [Mr. Ramsay] wanted, to be assured of his genius, first of all, and then to be taken within the circle of life, warmed and soothed, to have his senses restored to him, his barrenness made fertile, and all the rooms of the house made full of life" (42). Mrs. Ramsay regularly meets these steep demands, but providing constant attention and reassurance of this kind often becomes exhausting labor, which wears away at one's sense of self. There is no question that Mrs. Ramsay is an advocate for the power one can wield in the home, but Woolf tells us, through Lily, that we should not shy away from wanting something different if the cost of marriage proves too dear. 
For the most part, Mrs. Ramsay chooses to ignore her disquieting feelings toward her life, quickly summoning a kindly change of perspective to stamp out unwanted thoughts, like so many intrusive roaches. For her, this is par for the course, and she expects Lily and her kind to accept the same. As Ilona Bell posits in "'Haunted by Great Ghosts': Virginia Woolf and To The Lighthouse," Woolf was greatly preoccupied with the concerns of traditional motherhood, a preoccupation stemming from her mother's death. According to Bell, To The Lighthouse presents us with "1) how balanced and fully imagined is her portrait of Mrs. Ramsay; 2) how closely Lily Briscoe comes to Woolf's own vision of truth, truth that embraces the 'undeniable, everlasting, contradictory things' Mrs. Ramsay saw but tried to conceal with the 'relief of simplicity.' Woolf overcame the feeling of hardship and grievance caused by her mother's death, and was thus able to describe her mother and express her own feelings without bias or impediment" (151). Woolf attains "relief" after years of measuring her life by her mother's metric, experiencing something similar to Lily's relationship with Mrs. Ramsay, that pull which longs to bring women into the fold. We can propose that Woolf feels a kinship to Lily as an artist in the thrall of another woman - perhaps this is why Woolf lets Lily succeed, bestowing the vision upon her which allows her to synthesize conflicting feelings for Mrs. Ramsay through her painting.

In fact, in her essay Crater explores the notion that Lily is the first of Woolf's characters who survives deviating from societal norms:

Lily Briscoe is not willing to be martyred. In To the Lighthouse, Lily Briscoe encounters the figure of Woman in the person of Mrs. 
Ramsay...and finds an alternative to the identity they offer through her art. She explores the gap between her own daily experience and the ideology pressed upon her; she dives into the underwater world of consciousness, and is the first of Woolf's characters to survive the passage, to return and create from this gap, establishing new cultural alternatives. (125)

The significance of this achievement bears mentioning, seeing as Woolf may be highlighting the importance of Lily as an artist under pressure, unlike previous characters punished by their worlds. Lily does not only need to deviate; she intends to create, and this act of creation saves her.

Now, this being a novel primarily about the Ramsay matriarch, Charles Tansley's contributions from the masculine front are not as varied. We don't have multiple examples of his impositions upon different women, as we do with Mrs. Ramsay. But, we endure his echoing presence in Lily's mind. Most notably, we encounter the masculine sphere's intrusion when Lily becomes dissatisfied with her painting:

She could have wept. It was bad, it was bad, it was infinitely bad! She could have done it differently of course; the colour could have been thinned and faded; the shapes etherealised; that was how Paunceforte would have seen it. But then she did not see it like that. She saw the colour burning on a framework of steel; the light of a butterfly's wing lying upon the arches of a cathedral. Of all that only a few random marks scrawled upon the canvas remained. And it would never be seen; never 
be hung even, and there was Mr. Tansley whispering in her ear, "Women can't paint, women can't write ... " (54)

Woolf begins by providing insight into the mind of the artist, usually at war with herself over her work, agonizing over the details, finding her skills lacking when it comes to faithfully reproducing the grand concepts in her head. The artist must contend with the heartbreaking dissonance of finding her idea realized so crudely that everything she has done and could ever do appears miniscule, childish, and constantly wrong. This depiction of an artist's struggle is certainly common and relatable to artists of any gender, but then Woolf inserts Tansley's aside.

Fittingly, we do not see Tansley making this observation in real-time. Lily, even in the twentieth century, is a woman still somewhat removed from the masculine sphere. Yet she finds herself eternally influenced by it, by men's opinions and men's laws. Like his Victorian ancestors, Tansley asserts himself where he is not welcome, trying constantly to preserve order. The far-reaching influence of his comment is assured, as men's mandates ripple out to all of the community. Now Lily has an external foe to fight, alongside the artist's usual concerns. Unlike a male painter, lucky enough to act in the world because society expects him to belong there, only having to defend himself against personal assaults, Lily must carry the additional burden of criticism against her gender. Tansley does not comment, "Lily, you can't paint"; he passes down judgment: "Women can't paint."

The staggering weight of his proclamation becomes a burden Lily cannot shift, even as she sits at Mrs. Ramsay's table. During the dinner passage, both 
spheres work seamlessly together to attempt to subdue Lily. In short, Tansley becomes awkward and uncomfortable, unable to partake in the dinnertime discussion in the easy way of polite conversation, too concerned with the way in which he might be perceived. Mrs. Ramsay notices this, quietly expecting Lily to resolve the situation and engage Tansley in some breezy repartee. Lily understands, in the process perfectly describing the theory of the spheres, the "code":

There is a code of behaviour she knew, whose seventh article (it may be) says that on occasions of this sort it behoves the woman, whatever her own occupation may be, to go to the help of the young man opposite so that he may expose and relieve the thigh bones, the ribs, of his vanity, of his urgent desire to assert himself; as indeed it is their duty, she reflected, in her old maidenly fairness, to help us, suppose the tube were to burst into flames. (104)

Woolf outlines the ideology of the give-and-take which should be the Utopia of the spheres, where everyone helps each other and everyone has his or her place. Why should there be conflict? Each party performs a specific service for the other, no need for ruffled feathers. And yet, the prescriptive nature of the code becomes existentially suffocating to one who does not participate instinctually, awake to the process as Lily is: "She had done the usual trick - been nice. She would never know him. He would never know her. Human relations were all like that, she thought, and the worst...were between men and women. Inevitably these were extremely insincere" (105). 
Lily is correct, after all, in pointing out that she and Tansley do not know each other in any substantial way. By keeping to their separate spheres, Tansley will never consider her work worthy of critique for itself, outside of supposed gender constraints. He will never explain his scholarly pursuits in depth, not in the way that he would describe them to another man. For her part, Lily will never trust him with any secret or, when she can help it, with a glimpse of any of her paintings. They must exist divided, and Lily, at least, internalizes this thought and lets its truth envelop her. Tansley, as the representative for the masculine sphere, remains relieved at his companion's conversational help. He, unlike Lily, has received what he perceives as his due in this interaction and wants nothing else.

And here we come to Lily's source of personal strength, her work as an artist:

Then her eye caught the salt cellar, which she had placed there to remind her, and she remembered that next morning she would move the tree further towards the middle, and her spirits rose so high at the thought of painting to-morrow that she laughed out loud at what Mr. Tansley was saying. (106)

Earlier, as she sat at the table, Lily contemplated the placement of some elements in her painting, moving the salt cellar to mimic her concluding position and to prompt to make the changes later. Now, that salt cellar reminds her of something far more important. Lily has aspirations; she has a vision that she needs to make real, to put down on canvas and share. She has an obsession 
and a calling, and the artificialities of society cannot stop her. For the moment, the spheres have failed to contain her, although, most assuredly, she continues to feel their influence over the years, in a constant fight against being subdued.

Years later in "The Lighthouse," after both Tansley and Mrs. Ramsay have been long removed from her daily life, we see that Lily continues to chafe against the intrusion, unable to fully exert her powers as she takes up the old painting. Woolf has made the change all too clear with the "Time Passing" interlude - time has leisurely let nature rend the house apart and subsequently has let society put it back together - and yet, Lily must live with the echoes of Tansley in the shadow of Mrs. Ramsay:

Charles Tansley used to say that, she remembered, women can't paint, can't write. Coming up behind her, he had stood close beside her, a thing she hated, as she painted here on this very spot...parading his poverty, his principles...He sat, she remembered, working in a blaze of sun. At dinner he would sit right in the middle of the view. But after all, she reflected, there was the scene on the beach. One must remember that. It was a windy morning. They had all gone down to the beach. Mrs. Ramsay sat down and wrote letters by a rock. She wrote and wrote. "Oh," she said, looking up at something floating in the sea, "is it a lobster pot? Is it an upturned boat?" She was so short-sighted that she could not see. (182)

It bears noting that Lily thinks of both of them together, both having been her main antagonists during her stay in the house all of those years ago. Again, she 
faces the old problems, although her opponents are so far away that they have become ghosts. Tansley's exact words come back, as well as his problems. Tansley, after all, needs comforting as much as the rest of the masculine sphere. He thrusts his troubles at her, needing compassion. Woolf also makes a delightful allusion to Mrs. Ramsay's narrow-mindedness, drawing parallels between physical short-sightedness and her more general blindness to the realm outside of her sphere.

Thankfully, Woolf allows Lily the opportunity to transcend these restraints. She gives Lily the luxury of time and privacy to work on her vision, away from both the people in her immediate vicinity and the sharp reminders of the effort she has had to undergo because of Tansley, Mrs. Ramsay, and their ilk: "One pitied them, one brushed them aside, one had even a little contempt for them. They are at our mercy. Mrs. Ramsay has faded and gone, she thought. We can over-ride her wishes, improve away her limited, old-fashioned ideas" (199). Indeed, by allowing Lily this physical and mental space, Woolf here anticipates her thesis from A Room of One's Own. In an evocative passage of her fictionalized lecture, Woolf acknowledges the spheres and the unnecessary hardship they caused: "Among your grandmothers and great-grandmothers there were many that wept their eyes out. Florence Nightingale shrieked aloud in her agony...genius should be above caring what is said of it. Unfortunately, it is precisely the men or women of genius who mind most what is said of them" (56). Perhaps Woolf intends to have Lily's situation parallel that of the history of creative women, who wished to venture outside of their defined sphere. After all, 
according to Woolf's friend Lytton Strachey in his Eminent Victorians, Florence Nightingale faced notorious difficulty in pursuing her nursing appointment: "For not only was it an almost unimaginable thing in those days for a woman of means to make her own way in the world and to live in independence, but [her] particular profession... was at that time a peculiarly disreputable one" (113). And so, society's norms and traditions would rob the world of significant advancement had another woman been cowed into submission and denied autonomy. With this in mind, Woolf insists on allowing Lily to see her labors succeed:

Quickly, as if she were recalled by something over there, she turned to her canvas. There it was - her picture. Yes, with all its green and blues, its lines running up and across, its attempt at something. It would be hung in the attics, she thought; it would be destroyed. But what did that matter? she asked herself, taking up her brush again. She looked at the steps; they were empty; she looked at the canvas; it was blurred. With a sudden intensity, as if she saw it clear for a second, she drew a line there, in the centre. It was done; it was finished. Yes, she thought, laying down her brush in extreme fatigue, I have had my vision. (238)

Ultimately, the narrative shows us that the spheres are constrictive and harmful to the individual; more broadly, Woolf explores the ways in which society will always attempt to crush the solitary dissenter, forcing sacrifice from the woman who dares call herself an artist.

The key to Lily's transcendental moment in the end is that she be allowed to practice her art, that the compressing forces which have been acting upon her 
life be eased. By showing us this entirely symbiotic relationship with her work remembering that she is an artist has saved Lily in the context of society as much as overcoming this context has allowed her to thrive in her art - Woolf asserts the independence of feminine artistic thought and action. Furthermore, in order to let her have her vision, Woolf permits Lily to integrate aspects of her personality which her society traditionally considers both male and female. As Mark Spilka's essay "On Lily Briscoe's Borrowed Grief: A Psycho-Literary Speculation" notes when referring to Woolf's own set of skills, "Did she come armed, then, with [her father's] masculine weapons - hard impersonal muscular analytic artistry - as well as [her mother's] civilized feminine complement - restraint, sympathy, unselfishness" (4). After all, the separation of the spheres cannot benefit art; the exclusion from essential life experience is as disastrous to the artist as it would be to wrench the fibers from her brushes. Lily lives through a moment of understanding "undeniable, everlasting, contradictory things," and she becomes a creator. 


\section{THE ARTIST'S SACRIFICE IN "BETWEEN THE ACTS"}

Virginia Woolf continues to explore the manifestations of the feminine artist in her last novel Between the Acts. She sets the novel within the confines of one day in a country home, when the Olivers open their estate at Pointz Hall to the rest of the village for the annual pageant. Woolf presents Isa Oliver, wife to the heir of the family, and the reluctant mother to young children. Throughout the day, readers see Isa bristle at the expectations put upon her as a housewife; she recites poetry in her head and writes it in an account book to keep it hidden from her husband. With Isa, Woolf explores the artist who has yet to choose between seizing agency by creating within the framework of a traditionally feminine role (that of the housewife) or removing herself completely by diverting energy from her husband and children in order to pursue writing.

Woolf contrasts Isa with Miss La Trobe, the unmarried woman who has written and directed the day's play. Miss La Trobe appears to have sacrificed social standing in order to focus on writing - as a result, the villagers tend to forget her most of the year. Still, Isa's dissatisfaction with her life suggests that her surrender to respectability yields little in the way of rewards, while La Trobe, ill-treated, maintains the ability to create.

Ultimately, Isa is as obsessive about writing as La Trobe. She constantly thinks about poetry to the point where she becomes distracted in her duties as a housewife, duties which she finds abhorrent. Likewise, on the eve of her latest perceived failure, La Trobe, often neglected and occasionally a target for the 
amusement of others, immediately begins working on a new play to present to the same community which consistently misunderstands her work.

The writing continues for both despite incompatibilities with lifestyle and perceived public failure. Indeed, Isa may write and think about what to write as much as La Trobe does, yet as far as the text shows us, La Trobe, at least currently childless and unmarried, lives alone in a cottage and thus has opportunities to continually plug away at her work. Her small village society has, therefore, branded her an outcast, a woman who would rather live in solitude instead of run a household and entertain dinner guests; she has sacrificed normality in the name of keeping herself free to write. Conversely, Isa has married into a wealthy enough family and, as a young wife, manages the requirements of home and hearth. Because she dreams in poetry, this life represents drudgery, a choice she makes to keep herself respectable.

As Woolf shows us with La Trobe and her status as a barely tolerated outcast, often the life of a female artist demands she sacrifice something in order to pursue the work she deems most important. We also see this theme emerge for Woolf with Clarissa Dalloway in Mrs. Dalloway and with Lily Briscoe in To the Lighthouse; however, in Between the Acts Isa has not decided what is worth the sacrifice. Her negative feelings toward her family and her duties as one of the hosts of the pageant denote that perhaps she cannot cultivate fulfillment from the life she needs to lead as a conventional upper-class wife, yet she remains reclusive with her writing because she cannot countenance the resultant breach with society if she were judged for her work as a woman artist. 
And Isa is an artist, for we learn that, not only does she keep an account book hidden away with her poetry, she composes throughout the day even as she feels harried to complete her obligations to the household and its guests. From the beginning, Woolf begins to unravel her character before our eyes.

For a start, we have an example of Isa's romantic imagination in the scene with Mr. Haines, the gentleman farmer. "She had met him at a Bazaar; and at a tennis party. He had handed her a cup and a racquet--that was all. But in his ravaged face she always felt mystery; and in his silence passion" (5). Isa has raised the quotidian to the lofty heights of magic and ardor, creating a connection with this man where truly there is nothing concrete, spinning a story for herself already in a manner that will take her away from her "stockbroker husband," with whom she is generally unhappy. She even thinks in terms of story and arc as she attempts to forgo her fervor for Mr. Haines in order to encourage her relationship with her husband into something more loving, "Outside, on the washstand, on the dressing-table, among the silver boxes and tooth-brushes, was the other love; love for her husband...'The father of my children,' she added, slipping into the cliché conveniently provided by fiction. Inner love was in the eyes; outer love on the dressing table" (14). The passage above sets a twofold purpose as Woolf shows Isa's familiarity with an author's conventions while also highlighting her attempts to cling to her married life, trying to cast it as ideal and profound.

Isa intends to ground her relationship with her husband in the objects which represent their life together, the objects of the private room shared by husband and wife. She intends to force the belief that these things represent 
stability and long-lasting companionship; however, Woolf's text shows these trappings are hollow. As we read on, we see that Isa has no space in these rooms, and no time in which to think freely by herself, robbing her of the energy to write. In actuality, her husband and children can access all that she possesses. Yet she continues to write and think about writing, fighting to carve some room in her own life, even as she holds poetry tightly to her chest.

While an artist does not strictly need to release her creations into the world, Patricia Kindlienst Joplin argues for the value of having an audience in "The Authority of Illusion: Feminism and Fascism in Virginia Woolf's Between the Acts." She explores - in relation to Woolf's wartime mindset - Miss La Trobe's role as the writer and director of the pageant. The disasters during the production signify that an artist without an audience is left at sea: "Shocked and frightened by the effect upon her inner life of the loss of her audience to the general panic and suffering of war, Woolf was moved to make a work of art that openly explored the artist's need for her audience" (90). When the play ends, La Trobe refuses to step onto the stage and meet the reaction. Because she is a playwright, her art exists outside of her persona and she need not perform it; the audience can judge it and be affected by it without her direct presence. She needs them to see her work, wills them to understand it, yet once she has failed to make a connection, she can avoid confronting their response because she never presents her self for artistic assessment. Certainly, one can consider her relationship with her audience and her art as the reverse of Isa's. 
As a housewife, Isa's contributions require that she face the world. After all, the product is her performance as the lady of the house; however, because she does not actively strive to create within those parameters as Clarissa Dalloway does, we can conclude that this is a safer relationship with society than one of artist and audience, where the perceptions of the audience affect the artist's self-esteem regarding her work. In her capacity as a housewife, Isa merely exists and carries out the minimum of her responsibilities, sparing little thought to the tasks. Conversely, because Isa does connect with her writing as an artist identifies with her work, constantly obsessing and reworking, she steers clear of sharing it. In the beginning of the novel, her relationship with an audience is willfully nonexistent lest the audience hurt her. La Trobe, on the other hand, presents her work publicly and is thus vulnerable to the opinion of the audience. She cannot escape the emotional impact it has on her perception of her writing and directing, but La Trobe has grown to need it, striving to connect.

Still, because her work exists separately from her persona, La Trobe can afford to shield her face from society's opinion. She can showcase her work yet keep her person in relative anonymity. She presents her art for inspection and abuse; she feels the audience's eyes on the production throughout the duration of the pageant, and so her presence is not required at the end; the audience has already affected her mindset. To face them personally would be redundant. "'[l] propose a vote of thanks to the gifted lady ...' [Mr. Streatfield] looked round for an object corresponding to this description. None such was visible... It was an awkward moment. How to make an end? Whom to thank?...But no one spoke. 
Whom could they make responsible? Whom could they thank for their entertainment?" (194). La Trobe already bared herself to the audience at Pointz Hall; neither she nor they need her to make an appearance. The audience has experienced all that she could give them on this day, and any further interaction with her person will not increase their insight, nor will it lead to artistic growth on her part. She has already sacrificed a conventional life, so although judgment against the work affects her, she does not need to confront it directly to appease the society which already condemns her for creating at all.

Of course, since La Trobe considers her play to have floundered, prolonged contact with this crowd would only cause her distress: "She hadn't made them see. It was a failure, another damned failure! As usual. Her vision escaped her. And turning, she strode to the actors, undressing, down in the hollow, where butterflies feasted upon swords of silver paper; where the dish cloths in the shadow made pools of yellow" (98). The language Woolf chooses here conveys the despair of La Trobe's inability to connect and share her meaning. The actors, once reliant upon her for direction, can ignore her freely now; the decorations which drew the eye of the audience before, now become manmade trash polluting the nature of the hollow. La Trobe's mood shattered, she looks down into shadowed corners, noticing dingy dish cloths past their purpose. Woolf's writing here is reminiscent of Mrs. Dalloway, where she illustrates the way in which Clarissa can successfully compel people to join her vision, to experience, feel, and notice something new in the mundane. Clarissa connects successfully with her intended audience, while La Trobe struggles and 
thus she keenly feels her shortcomings in the failure at making them see her vision as she sees it.

Woolf also covers this struggle and lack of connection with the character of Lily Briscoe in To the Lighthouse. We see there a creator who finds it difficult to be accepted by the community of thinkers and should-be fellow artists. As a woman painter, she deals within the fringes of the establishment, while also feeling isolated in Mrs. Ramsay's world of women, scorned by the society to which she belongs by birth.

La Trobe experiences a similar isolation, as Melba Cuddy-Keane discusses in "The Politics of Comic Modes in Virginia Woolf's Between the Acts": "Bossy" is La Trobe's nickname and the players form under her in "little troops." The image of the commander suggests an unflattering connection...the negative implications of such authority and power are voiced by another character, Isa, who understands how leadership entails separation from community and who rejects "the frantic cries of the leaders who in that they seek to lead desert us" (183). La Trobe is almost such a negative authority figure, but other factors counteract her domineering role. Suffering agonies because the success of her play is at least in part dependent on the response of the spectators, she tells them, "A tyrant, remember, is half a slave" (218-19). And she stays hidden behind a tree...even refusing to appear for the audience's thanks. (278) 
One might characterize La Trobe's relationship with her actors and set designers as antagonistic due to her status as a woman of relative power. She cannot be too exacting in her role as director without incurring the term "bossy." The villagers force her to tweak her ideas (to their detriment, she feels), "'Curse! Blast! Damn 'em!' Miss La Trobe in her rage stubbed her toe against a root. Here was her downfall; here was the Interval. Writing this skimble-skamble stuff in her cottage, she had agreed to cut the play here; a slave to her audience" (94). Her pacing must be disturbed for the sake of showing her play; she wants to connect with her audience, and tries in the best ways that she can, even as she knows she loses momentum. But she endures this too in order to create form for her vision, attempting to bring it to life, however imperfect.

In the end, the only human interaction La Trobe requires is with the audience for her work. Woolf tells us that no one seems to know her, and people refer to her as "Miss Whatshername" as often as not (184). She appears only to exist at the time of the pageant, and she can do this because, unlike Isa, nobody expects anything of her outside of artwork - she certainly does not expect anything else from herself. So, away from the pageant, she lives in solitude: "The old woman looked down at the dead flowers she was carrying and cut her. The women in the cottages with the red geraniums always did that. She was an outcast. Nature had somehow set her apart from her kind" (211). Woolf does not show us the details of La Trobe's life outside of this day, but we can deduce her loneliness. As she walks home, people whisper about her, yet they do not engage her. But the artistic drive within her reminds La Trobe that she cannot 
stop creating for these people. She can endure their disdain, so long as they build her the stage for the pageant; this sacrifice she can make.

After all, La Trobe's last scene shows us that, destroyed though she may have appeared, she will write a new play:

They had been talking about Bossy as they called her--it didn't matter.

She took her chair and looked through the smoke at a crude glass painting of a cow in a stable; also at a cock and a hen. She raised her glass to her lips. And drank. And listened. Words of one syllable sank down into the mud. She drowsed; she nodded. The mud became fertile. Words rose above the intolerably laden dumb oxen plodding through the mud. Words without meaning--wonderful words. (211)

If she has always felt separate from the world, at least she can express herself to it, creating what she must. Miss La Trobe finds that exercising her creativity is worth any conflict, and her peculiar secluded lifestyle gives her time for contemplation, a drink, a rest, allowing her to overcome the mediocre trappings and focus on what she needs to write. That she can thus work the soil steadily and harvest anything is akin to a miracle, as the "dumb oxen" - her disapproving neighbors perhaps, weighed down with societal demands - keep their eyes down and thus see nothing but the mud while La Trobe's mind is allowed to wonder and return as it pleases, marking her paper.

Isa, on the other hand, is unwilling to take a step away from the conventional realm she knows, unsatisfying though it may be. To consider Isa's artistry, we must begin by exploring her discomfort in the role she already 
occupies, that of wife and mother. Clarissa Dalloway managed to transform the duties of the position into materials for creation, becoming an excellent hostess, detail-oriented and grand, able to transcend and to guide her audiences through new experiences. Unfortunately for Isa, she does not share Clarissa's ability to mine this artistic potential. Instead, Isa fails to connect her responsibilities with fulfillment at all.

As a wife and mother, the eternal hostess of the manor, Isa would always need to consider the impression that her aspect and bearing would have upon those in her society. To retain public acceptance, she needs to repress and permanently hide part of herself. While it is possible that a woman can find power in performing the duties of a housewife, Isa's animosity toward many aspects of her life does not point toward an amicable relationship with the position: "How am I burdened with what they drew from the earth; memories; possessions. This is the burden that the past laid on me, last little donkey in the long caravanserai crossing the desert. 'Kneel down,' said the past. 'Fill your pannier from our tree. Rise up, donkey. Go your way till your heels blister and your hoofs crack'" (155).

With this passage, Woolf indicates that Isa lacks whatever natural inkling or skill there is to wifehood and motherhood which makes this work bearable. The weight of the feminine legacy as promoted by society has condemned her to this seemingly interminable toil, from which she receives little satisfaction. Preempting La Trobe's musings later in the narrative, Isa casts herself as the dumb, plodding animal. The comparison to a beast of burden illustrates the relentlessness with which she must work and underlines an implied absence of 
agency in her life. Her role, as she perceives it, is to bear what the world has decided will be her load, and she must continue to do so until her death, like the work beasts do. Because her family demands it, Isa does not own her time; she can barely spare the room in her mind for her thoughts.

Throughout the day, to help her carry out tasks, she exercises poetic writing skills in an attempt to generate loving feelings for her husband Giles despite her apathy, but her passion for Mr. Haines, the gentleman farmer, keeps reminding her that she does not love Giles in the way that she should: "'He is my husband,' Isabella thought, as they nodded across the bunch of many-coloured flowers. 'The father of my children"' (47). She repeats this phrase, "father of my children" to ease her mind into accepting him, to trick herself into love and to remember the shared history of the marriage; however, the process is repetitive and laborious, only helping to contrast the easy way in which she romanticizes encounters with Haines. Moreover, and regrettably in terms of her chosen coping strategy, Isa also lacks in traditional motherly feelings.

Woolf outlines the distance between mother and child early in the novel as well. Isa looks at her son George playing from the window, and tries feebly to get his attention: "She tapped on the window with her embossed hairbrush. They were too far off to hear. The drone of the trees was in their ears; the chirp of birds; other incidents of garden life, inaudible, invisible to her in the bedroom, absorbed them" (14). Woolf's use of language here highlights how isolated they are from each other. The children do not hear her because they are engrossed in 
their play, and she cannot join it. Their bond does not include sharing their experiences, and her children's feelings remain "invisible" to her.

Even William Dodge, a newly-made acquaintance, can see that the children stifle Isa. "He made a bee-line for her. He was her little boy, apparently, her son, her George. She gave him cake; then a mug of milk. Then Nurse came up. Then again she changed her dress. This time, from the expression in her eyes it was apparently something in the nature of a strait waistcoat" (105). Even though all Isa does for George is hand him food before Nurse takes him away, she already feels suffocated, and Dodge sympathizes enough to understand that Isa does not know how to interact meaningfully with this child any more than she can desire her husband.

After witnessing this transaction between mother and child, Dodge informs us that Isa looks trapped, and we can attribute authority to his testimony as Woolf shows us that Dodge himself is awkward in Pointz Hall. When they meet, Isa notes him twitchy and overly self-conscious, hyper-aware of his companion Mrs. Manresa's excesses in frivolity (38). Woolf has him stand somewhat apart from the group during the picnic, underlining the separation at once when Giles' father attempts to engage Dodge in conversation: "He sat staring, 'I beg your pardon, sir?' he said...'I was looking at the pictures.' The picture looked at nobody. The picture drew them down the paths of silence" (45). His demeanor disturbs the easy society and marks him an outcast, even later attracting aggression from Giles, who considers him a proxy for perversion (99). 
Thus separated, Dodge invites a passing emotional intimacy with Isa and Mrs. Swithin, Giles' put-upon widowed aunt. Both women feel a degree of comfort when alone with him, and to some extent, speak rather freely with him, recognizing kinship. Indeed, twice in quick succession, people identify Dodge as an artist when he shows continued interest in paintings; Woolf has him deny this label, citing some other profession for his livelihood, and he reflects Isa's struggles between artistic pursuits and the traditional role she has been tasked to fulfill. Isa notices the parallels as she watches him speak with others: "'Why's he afraid?' Isabella asked herself. A poor specimen he was; afraid to stick up for his own beliefs - just as she was afraid, of her husband" (50). Unlike La Trobe, Dodge and Isa both fail to follow their visions out of fear.

Yet Isa's social expectations only smother her as a member of the family hosting this event. She does not take a leading role as Clarissa would have done, barely condescending to pass out sandwiches to the guests. Thus we can conclude that Isa can continue her life with the Olivers only at the expense of her artistic fulfillment. After all, while Clarissa finds focus in the details of homemaking, Isa is fatigued and distracted.

For example, even during her simple morning phone call to order lunch, she would rather write poetry:

"There to lose what binds us here," she murmured. "Soles. Filleted. In time for lunch please," she said aloud. "with a feather, a blue feather...flying mounting through the air...there to lose what binds us here..." The words weren't worth writing in the book bound like an account 
book in case Giles suspected. "Abortive," was the word that expressed her. She never came out of a shop, for example, with the clothes she admired; nor did her figure...please her. She looked like what she was: Sir Richard's daughter; and niece to the two old ladies at Wimbledon. (15) Woolf immediately demonstrates that Isa's life does not belong to her in full; she needs to attend to matters of the household, which encroach even upon the time she needs to ready herself in the morning. Her responsibilities chase her thoughts, and even though these are the duties of a financially privileged woman, we can see them become more arduous to Isa as the day progresses.

Part of Isa's agitation with this small crowded life has the basis in Woolf's reality. She had moved to the country during the conception and writing of the novel, and she did not take to it easily. "Ding dong bell ...ding dong-why did we settle in a village? And how deliberately we are digging ourselves in!" (Diary 290). Woolf's environment constantly interrupted her, and she channeled this frustration into Isa's inability to sit and write undisturbed. Similarly, in this novel we also encounter Woolf's A Room of One's Own illustrated perfectly, as the housewife has little time to devote to art and no physical sanctuary to which she can escape. The poetic fragment of a feather flying free with nothing to strike it back down appears like a prayer for release, a yearning. Isa's musings have the potential to become what she considers poetry, something worthy of writing down, of remembrance, but neither she nor we will ever know absolutely, because someone must order the fish fillets for the family's meal. Throughout the 
day, we see the little interruptions adding up to a cumulative sense of wasted potential.

Isa calls herself "abortive" in this early passage, defining herself as unfinished and discarded. It suggests Isa feels that she lacks the drive to commit to something, and - to connect her to the abandoned poem - thus finds that she lives misplaced, instead of free. After all, Isa does not connect with the persona she uses to interact with her fellow-man. Her relations revolve around marriage and lineage - her father, aunts, husband - never around what she has written; indeed, she thinks and writes completely in seclusion despite her lack of physical privacy.

Isa's keeping her poetry hidden in a plain book normally used for mundane accounts harkens back to the veneer of tolerant femininity she applies to cover her thoughts, persevering through the humdrum work of her life, keeping silent, planning meals, moving through the world as a respectable wife and mother. To introduce an audience to her writing would generate a vulnerability which she prefers to avoid. Furthermore, by persisting in hiding, she can continue to be evaluated on the external factors of her family relations, which she does not hold as closely to herself as she does her poetry. Not only would people then judge her on artistic concerns, but she would stand to lose her current high status. She would also have to fight against gendered expectations in order to share her art; to write at leisure, she would need to focus on her needs and disregard her husband's, their children's. 
As a nudge toward publicly sharing her art, Isa does begin to reveal her poetry to Dodge in the novel:

Isa dragged her chair across the gravel, muttering: "To what dark antre of the unvisited earth, or wind-brushed forest, shall we go now? Or spin from star to star and dance in the maze of the moon? Or. ..."

"Songs my uncle taught me?" said William Dodge, hearing her mutter. He unfolded the chair and fixed the bar into the right notch. She flushed, as if she had spoken in an empty room and someone had stepped out from behind a curtain.

"Don't you, if you're doing something with your hands, talk nonsense?" she stumbled. (51)

Although she encounters her first involved audience in Dodge, she cannot bear that he has heard her. His interruption startles her after a lifetime of muttering with only her ears to listen, and she reacts as if he walked in on something more universally intimate. Lacking in confidence, she dismisses her poetry as worthless distraction.

Of course, to Isa, this is the most secret, protected part of her life, and her ongoing reluctance to share it only serves to trap her in the silences of Pointz Hall. Nobody in that household knows of Isa's writing, of the poems she composes as she goes about the oftentimes tedious business of running it. Crucially, Woolf notes that the reason Isa specifically keeps her writing in an 
account book is "in case Giles suspected" (15). Not only must she keep these activities separate from her husband, with whom one should ideally share major thoughts and interests, but she cannot find a private space to secure her writing from him. Woolf implies that Isa owns nothing material which Giles cannot reach.

Patricia Kramer categorizes the household as a tableau for an ancient war. In "Virginia Woolf's Matriarchal Family of Origins in Between the Acts," Kramer sorts the characters into two separate camps, warriors and thinkers: "Giles exhibits the hostility toward goddess-like women characteristic of 'heroes.' When he pursues Manresa because she flatters him, and only relates to Isa as his wife and mother of their children, he excludes Isa's artist or goddess identity from his reality" (172). To Isa, Giles, her "stockbroker husband," represents the traditional ideas which have led her into this unfulfilling life. Let us remember, Isa admits that she fears him and the power his opinions - a reflection of society's can have over her life (50). She believes his sensibilities too rigid to accept any deviance from the norm on her part, and so she hides most of herself away from him, thinking he will not understand, bathed as he is in the advantages of his station. Even if Isa continues as his wife, he will never respect her as a person of worth - not while her status comes from her relationship to him.

To cope with her living conditions, Isa deals with her burdens by thinking of what to write, even when she cannot reach her book. Her hidden words skitter throughout her scenes in the novel, her art becoming almost a compulsion for want of an outlet, now a coping mechanism. We see one such example when the audience of La Trobe's play becomes tense: 
All their nerves were on edge. They sat exposed. The machine ticked.

There was no music. The horns of cars on the high road were heard.

And the swish of trees. They were neither one thing nor the other;

neither Victorians nor themselves. They were suspended, without

being, in limbo. Tick, tick, tick went the machine.

Isa fidgeted; glancing to right and to left over her shoulder.

"Four and twenty blackbirds, strung upon a string," she muttered.

"Down came an Ostrich, an eagle, an executioner,

'Which of you is ripe,' he said, 'to bake in my pie?

Which of you is ripe, which of you is ready."' (178)

The scene deals with feeling exposed, something we already know that Isa fears. Isa lives in limbo now, perhaps realizing that the life she has chosen does not suit her, that the sacrifices she continually makes on its behalf devour her slowly instead of strengthening her resolve. Isa is not herself, and her time might run out before she can change this. Furthermore, the poem itself, with its references to birds and executions, leads one to think of prey. Certainly, Isa might see herself a victim of society's standards, which have forced her to repress her nature.

As La Trobe thinks nature marked her out to be different from her peers, so it could be said of Isa. In "The Nature of Between the Acts," Harriet Blodgett writes, "The carpe diem theme [of the novel] is less consequential than the reminders that between the acts of our lives we will, are the many acts we do not will...For better and worse, there are 'emotions in which the mind has no share'....and choices which are made for us, from little George's instinctive terror 
at Bart's monster face to Isa's muttering poetic incantations to relieve her exacerbated soul" (30). We need to account for the fact that, despite everything, Isa continues writing. She might be rather prolific, as supported by the fact that she never stops thinking about what to write. The inclination to write beckons in a way that nothing else in her life ever does, and she continues to nurture it as much as she can despite her aversion to an audience.

To conclude, we return to the beginning of the novel, in the morning when Isa stands in front of her mirror. "[She] stood in front of the three-folded mirror, so that she could see three separate versions of her rather heavy, yet handsome, face; and also, outside the glass, a slip of terrace, lawn and tree tops" (13). Woolf warns us here that Isa is fractured and, as we learn later, cannot properly synthesize her persona to fit the mold in which she is pressed. Christopher Ames discusses this mirror in "Carnivalesque Comedy in Between the Acts," concluding that "the recurrent Woolfian theme of multiple selves emerges...The multiplication of mirror alerts us to the theme of the fragmented self-a theme that culminates in Between the Acts with the actors accosting the audience with multiple mirrors to conclude the pageant. Given the complexity of the fragmented self, it behooves one to adopt a role" (396).

We can read Woolf's ambiguous ending - Isa and Giles alone in a room for the first time all day: "Then the curtain rose. They spoke" - as a hopeful signifier that Isa will take steps to adopt her rightful role, that this unhappy married couple has gained courage at last to engage in meaningful discourse, an exchange of experiences (219). For once, they will have a moment alone with each other. 
Despite Woolf's refusal in giving us the contents of their conversation, to finish her novel with them speaking apart from others - something they have not done in her text - implies a change in their trajectory, something different at last. Although it appears Isa has chosen at the start of Between the Acts, for better or worse, the life of the housewife and mother, she nevertheless cannot achieve artistic fulfillment, and perhaps Woolf's ending indicates a sea change, with she and her husband finally occupying the same intimate space and initiating a dialogue without the normal pretenses; the wish here is, perhaps, that Miss La Trobe's pageant and the moments surrounding it managed to resurrect something Isa thought dead.

To be sure, Between the Acts prioritizes sacrificing for art over suffering for social acceptance. La Trobe lives a difficult life, but her writing provides spark, the drive to do it all over and over. The artist's life, despite its problems, appears worthwhile when contrasted with Isa's slow asphyxiation. Isa has made a hollow sacrifice, working against her instinct. And much in the way that society arbitrarily divides itself, causing people like Isa to suffer needlessly, "It was a pity that the man who had built Pointz Hall had pitched the house in a hollow, when beyond the flower garden and the vegetables there was this stretch of high ground. Nature had provided a site for a house; man had built his house in a hollow" (10). 


\section{LIST OF REFERENCES}

Ames, Christopher. "Carnivalesque Comedy in Between the Acts." Twentieth Century Literature 44.4 (1998): 394-408. Web. 24 Feb. 2015.

Bell, Ilona. "'Haunted by Great Ghosts': Virginia Woolf and To the Lighthouse." Biography. 9.2 (1986): 150-75. Web. 25 Feb. 2015.

Blodgett, Harriet. "The Nature of Between the Acts." Modern Language Studies 13.3 (1983): 27-37. Web. 24 Feb. 2015.

Caramagno, Thomas C. The Flight of the Mind: Virginia Woolf's Art and Manicdepressive IIIness. Berkeley: $U$ of California, 1992. Print.

---. "Manic-Depressive Psychosis and Critical Approaches to Virginia Woolf's Life and Work." PMLA. 103.1 (1988): 10-23. Web. 9 Nov. 2013.

Cramer, Patricia. "Virginia Woolf's Matriarchal Family of Origins in Between the Acts." Twentieth Century Literature 39.2 (1993): 166-84. 24 Feb. 2015.

Crater, Theresa L. "Lily Briscoe's Vision: The Articulation of Silence." Rocky Mountain Review of Language and Literature. 50.2 (1996): 121-36. Web. 25 Feb. 2015.

Cuddy-Keane, Melba. "The Politics of Comic Modes in Virginia Woolf's Between the Acts." PMLA 105.2 (1990): 273-85. Web. 24 Feb. 2015.

Fawcett, Millicent Garrett. "The Education of Women of the Middle and Upper Classes." Macmillan's Magazine 17 (1868): 511-17. Print.

Klindienst Joplin, Patricia. "The Authority of Illusion: Feminism and Fascism in Virginia Woolf's Between the Acts." South Central Review 6.2 (1989): 88104. Web. 24 Feb. 2015.

Krukowski, Lucian. "Appreciation, Obligation, and an Artwork's End." Journal of Aesthetic Education 17.2 (1983): 31-45. Web. 24 Feb. 2015.

Langland, Elizabeth. "Nobody's Angels: domestic Ideology and Middle-Class Women in the Victorian Novel." PMLA 107.2 (1992): 290-304. Web. 25 Feb. 2015.

Lee, Hermione. Virginia Woolf. New York: Vintage Books, 1996. Print. 
Littleton, Jacob. "Mrs. Dalloway: Portrait of the Artist as a Middle-Aged Woman." Twentieth Century Literature 41.1 (1995): 36-53. Web. 24 Feb. 2015.

Moi, Toril. Sexual/Textual Politics Feminist Literary Theory. London: Routledge, 1985. Print.

Smythe, Karen. "Virginia Woolf's Elegiac Enterprise." NOVEL: A Forum on Fiction. 26.1 (1992): 64-79. Web. 23 Jul. 2015.

Spilka, Mark. "On Lily Briscoe's Borrowed Grief: A Psycho-Literary Speculation." Criticism 21.1 (1979): 1-33. Web. 24 Jul. 2015.

Strachey, Lytton. Eminent Victorians. London: Penguin Books, 1986. Print.

Woolf, Virginia. A Room of One's Own. San Diego: Harcourt, 1929. Print.

---. Between the Acts. San Diego: Harcourt, 1941. Print.

---. Mrs. Dalloway. London: Harcourt, 1925. Print.

---. To The Lighthouse. New York: Everyman's Library, 1927. Print.

Woolf, Virginia, and Leonard Woolf. A Writer's Diary: Being Extracts from the Diary of Virginia Woolf. San Diego: Harcourt, 1982. Print.

Zwerdling, Alex. "Mrs. Dalloway and the Social System." PMLA, 92.1 (1977): 6982. Web. 24 Feb. 2015. 